\title{
Ekstraksi Pola Kesalahan Jawaban Siswa Menggunakan Algoritma Apriori
}

\author{
Sandi Fajar Rodiyansyah ${ }^{1}$, Ardi Mardiana ${ }^{2}$ \\ ${ }^{1,2}$ Program Studi Teknik Informatika, Fakultas Teknik, Universitas Majalengka \\ ${ }^{1,2}$ Jl. KH. Abdul Halim No. 103 Majalengka, Jawa Barat 45418 Indonesia \\ Email korespondensi: sfr@ft.unma.ac.id
}

Dikirim 19 Juli 2017, Direvisi 15 Agustus 2017, Diterima 22 Agustus 2017

\begin{abstract}
Abstrak - Ujian Nasional (UN) adalah tahapan akhir seorang siswa dalam menyelesaikan studinya pada jenjang pendidikan formal yang sedang dijalani. Setiap tahunnya siswa berupaya mempersiapkan sebaik mungkin dalam menghadapi ujian tersebut. Untuk membantu persiapan siswa dalam menghadapi ujian nasional, umumnya sekolah membuat kegiatan program jam tambahan. Pada kegiatan ini, biasanya dilakukan pembahasan soal ujian tahun-tahun sebelumnya. Dengan demikian, guru memerlukan teknik pemilihan pembahasan soal yang perlu diberikan untuk efisien waktu. Algoritma apriori digunakan untuk analisis ekstraksi pola kesalahan jawaban siswa. Hasil yang didapat dari penelitian ini adalah teknik ekstraksi pola kesalahan jawaban siswa. Pola yang dimaksud adalah hubungan soal kesalahan suatu soal dengan soal yang lain sehingga guru bisa fokus memberikan tambahan materi pada soal-soal yang masih dijawab salah oleh siswa..
\end{abstract}

Kata kunci - ujian nasional, kesalahan jawaban, ekstraksi pola, apriori, jawaban siswa

Abstract - Ujian Nasional (UN) is the final stage of a student in completing his studies at formal education level. Each year students prepare for the exam. To assist the preparation of students in facing the UN, schools generally make extra hour lessons. In this activity, usually the discussion about the test of the previous years. Teachers need the technique of choosing the discussion of the problem that need to be given for time efficiency. Apriori Algorithm is used for the analysis of the student's error response pattern. The result of this research is the technique of wrong answer pattern. The pattern in question is the relationship between wrong answer with another, so that teachers can focus on providing additional material on the questions that are still answered wrong by students.

Keywords - ujian nasional (national exam), wrong answer, pattern extraction, apriori, student answer

\section{PENDAHULUAN}

Sejak munculnya Ujian Nasional pada tahun 2001/2002 (Ujian Akhir Nasional) yang kemudian diperkuat dengan adanya peraturan pemerintah Republik Indonesia Nomor 19 tahun 2005, tampaknya UN tidak terlepas dari pro dan kontra. Saat ini ujian nasional dilaksanakan dalam rangka pemetaan mutu program satuan pendidikan, dasar seleksi masuk jenjang pendidikan selanjutnya, penentuan kelulusan dan sebagai dasar pemberian bantuan dan binaan dalam rangka peningkatan mutu pendidikan. Berbagai upaya dilakukan oleh pihak sekolah untuk membekali siswa dalam menghadapi ujian nasional diantaranya dilakukan program jam belajar tambahan yang diisi dengan pembahasan soal ujian tahun-tahun sebelumnya. Pemberian jam pelajaran tambahan yang masih memiliki keterbatasan, diantaranya adalah keterbatasan waktu karena kebanyakan dilakukan hanya beberapa bulan menjelang ujian nasional. Sehingga guru memerlukan suatu teknik untuk memilih pembahasan soal yang perlu diberikan kepada siswa dan yang tidak perlu diberikan kepada siswa.

Algoritma apriori digunakan untuk mengekstrak pola hubungan satu data dengan data yang lain yang dalam hal ini hubungan antara satu soal dengan soal yang lain. Telah banyak dilakukan penelitian mengenani aturan asosiasi diantaranya menggunakan algoritma apriori untuk pengenalan pola transaksi peminjaman buku pada perpustakaan [1]. Penggunaan algoritma apriori untuk diimplementasikan pada sistem yang mampu membaca pola persediaan alatalat kesehatan pada sistem penjualan apotek [2]. 
Pengenalan pola transaksi penjualan barang pada perusahaan retail dengan apriori [3].

Dengan menggunakan data dalam bentuk semantic web yang disimpan dalam bentuk RDF atau OWL dengan data mengenai jamu, dilakukan pengolahan dengan menggunakan algoritma apriori. Hasil dari algoritma apriori ini adalah aturan-aturan asosiasi tentang komposisi tanaman jamu beserta dengan nilai support, confidence dan lift ratio [4].

Penelitian berikutnya adalah penggunaan Association Rule Mining pada data nilai mahasiswa Matematika ITS menggunakan algoritma Apriori. Pola yang ditemukan berupa hubungan nilai dari suatu mata kuliah dengan nilai mata kuliah yang lain [5]

Selanjutnya, algoritma Frequent Pattern Growth (FP-Growth) digunakan untuk membantu menemukan sejumlah aturan asosiasi dari basis data dengan menerapkan struktur data Tree atau disebut dengan FP-Tree. Implementasi menggunakan RapidMiner 5.3 untuk membantu menemukan pola yang akurat. Pola transaksi pembelian yang terbentuk memiliki frekuensi maksimal sampai 3 item set yaitu jika membeli Mie Instan maka membeli Kopi dengan nilai support= $65.5 \%$ dan nilai confidence $=100 \%$ dan jika membeli Roti dan Mie Instan maka membeli Kopi dengan nilai support $=50.8 \%$ dan nilai confidence $=100 \%$ [6]

Polusi udara di Surabaya disebabkan oleh bermacam-macam polutan baik alami maupun buatan manusia termasuk faktor meteorologis lainnya. Analisis dilakukan menggunakan aturan asosiasi dalam algoritma Apriori dengan data selama periode dua tahun, mulai Januari 2013 sampai dengan Desember 2014 yang diperoleh dari salah satu stasiun pemantau kualitas udara di Badan Lingkungan Hidup Surabaya. Setelah melalui tahapan proses dalam data mining dengan menggunakan algoritma Apriori maka akan dihasilkan beberapa aturan asosiasi dalam berbagai kondisi yang dapat dijadikan bahan kajian untuk beberapa periode selanjutnya [7].

Tanda tangan adalah bentuk pola unik yang dihasilkan seseorang sebagai penanda identitas yang ada pada suatu dokumen. Penelitian ini berupaya untuk mengembangkan teknik pengolahan citra pada tanda tangan dan mengidentifikasi pola citra tanda tangan berdasarkan nilai entropi. Hasil penelitian menunjukan bahwa sebaran nilai entropi pada tanda tangan asli mempunyai error 3,31\% dari total responden (30 responden). Nilai error ini merupakan nilai entropi yang keluar dari kelompoknya [8].

Data mining merupakan sebuah proses dari knowledge discovery (penemuan pengetahuan) dari data yang sangat besar [9]. Sementara itu, Association analysis adalah penemuan association rule yang menunjukan pola-pola yang sering muncul dalam data. Terdapat nilai support dan confidence yang dapat menunjukkan seberapa besar suatu rule dapat dipercaya [10].
Pada penelitian ini, diajukan suatu metode pemilihan materi soal yang perlu dibahas dan yang tidak perlu dibahas kepada siswa pada jam pelajaran tambahan dalam rangka persiapan ujian nasional. Penentuan soal yang perlu dibahas dan tidak perlu dibahas didasarkan pada pola kesalahan jawaban siswa pada ujian pretest. Dari hasil ujian pretest tersebut disamping nilai masing-masing siswa, dengan metode ini, guru akan melihat pola kesalahan jawaban siswa. Sehingga berdasarkan pola tersebut, guru dapat menentukan materi soal yang perlu dibahas dalam jam pelajaran tambahan untuk persiapan ujian nasional. Pendekatan ini merupakan pendekatan yang mengacu pada konsep association rule menggunakan metode apriori. Penggunaan algoritma ini didasarkan pada kesederhanaan proses yang dilakukan sehingga proses perhitungan dapat dilakukan dengan mudah dan penentuan pola kesalahan jawaban siswa dapat dilakukan dengan cepat..

\section{METODE PENELITIAN}

Pada Gambar 1 penelitian diawali dengan penentuan lokasi sekolah yang didasarkan pada data hasil ujian nasional periode sebelumnya. Pada tahapan ini juga dilakukan proses penentuan mata pelajaran sampel yang akan digunakan sebagai data sampel pada penelitian ini. Pada penelitian ini menggunakan mata pelajaran matematika sebagai mata pelajaran sampel, didasarkan karena matematika merupakan mata pelajaran yang dianggap sulit oleh siswa.

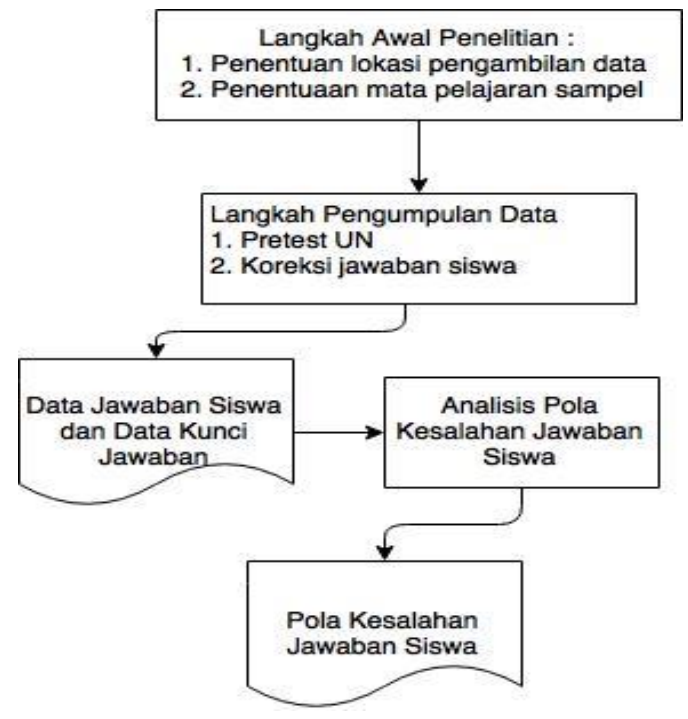

Gambar 1. Alur Mode Penelitian

Langkah berikutnya adalah dilakukan proses pretest Ujian Nasional kepada siswa tingkat akhir. Hasil pada penelitian ini menggunakan data hasil pretest UN sebanyak 40 siswa. Setelah pretest dilaksanakan kemudian dilakukan proses koreksi jawaban siswa. Data hasil koreksi jawaban siswa hanya memuat nomor siswa, nama siswa, nomor soal dan status jawaban pada soal tersebut apakah jawaban tersebut dijawab benar atau salah oleh siswa yang bersangkutan. 
Selanjutnya, data yang sudah didapat dari proses koreksi jawaban tersebut selanjutnya dilakukan proses analisis kesalahan jawaban siswa kemudian akan menghasilkan pola kesalahan jawaban siswa.

Algoritma apriori atau sering disebut juga dengan analisis asosiasi (association rule mining) adalah teknik data mining untuk menemukan aturan asosiasi antara suatu kombinasi item [11]. Misalkan $\mathrm{I}=\{\mathrm{i} 1, \mathrm{i} 2, \mathrm{i} 3, .$. in $\}$ merupakan himpunan items dan $\mathrm{D}$ merupakan himpunan database transaksi yang setiap transasi $\mathrm{T}$ merupakan himpunan item yang terkandung dalam transaksi T. Setiap transaksi diasosiasikan dengan identifier yang disebut TID. Aturan yang memenuhi minimum support (min_sup) dan minimum confidence (min_conf) disebut kandidat rule yang kuat. Berdasarkan konvensi, nilai support dan nilai confidence adalah nilai antara $0 \%$ sampai $100 \%$ sebanding dengan 0,0 sampai 1,0 [10].

Himpunan item disebut dengan itemset. Itemset yang mengandung $k$-items disebut $k$-itemsets. Sebagai contoh himpunan \{kopi, gula\} merupakan 2-itemset. Kecenderungan kemunculan itemset dalam sejumlah transaksi disebut frequency, support count atau count itemset.

Aturan asosiasi dilakukan dengan melalui dua langkah, yaitu,

1. Temukan semua frequent itemset tahapan ini juga sering disebut dengan analisa frekuensi tinggi. Hasil dari proses ini adalah sejumlah itemset dengan nilai support lebih besar atau sama dengan minimum support yang diberikan. Nilai support dari itemset $\{\mathrm{A}, \mathrm{B}\}$ dihitung dengan mengacu pada persamaan (1) dimana $\mathrm{s}$ adalah nilai support, frequency $(\mathrm{A}, \mathrm{B})$ adalah jumlah siswa yang menjawab salah pada nomor $\mathrm{A}$ dan $\mathrm{B}$ dan $\Sigma \mathrm{T}$ adalah jumlah siswa.

$$
s=\frac{\text { frequency }\{A, B\}}{\sum T} \times 100
$$

2. Menentukan strong rule dari frequent itemset, tahapan ini sering disebut juga dengan pembentukan aturan asosiasi. Hasil dari proses ini adalah semua rule yang memenuhi minimum support dan minimum confidence. Jika terdapat frequent 2-itemset $(\mathrm{A}, \mathrm{B})$ maka akan terbentuk suatu aturan $\mathrm{A} \rightarrow \mathrm{B}$ dan $\mathrm{B} \rightarrow \mathrm{A}$. Nilai confidence dari suatu kandidat rule $\mathrm{A} \rightarrow \mathrm{B}$ dihitung dengan mengacu pada persamaan (2) dimana $c$ adalah nilai confidence, frequency $(\mathrm{A}, \mathrm{B})$ jumlah siswa yang menjawab salah pada nomor A dan B dan frequency(A) adalah jumlah siswa yang menjawab salah pada nomor A.

$$
c=\frac{\text { frequency }\{A, B\}}{\text { frequency }\{A\}} \times 100
$$

\section{HASIL PENELITIAN}

Seperti yang telah dijelaskan sebelumnya, setelah proses pretest ujian nasional dilaksanakan, kemudian dilakukan proses koreksi jawaban siswa pada pretest tersebut. Data hasil koreksi tersimpan dalam struktur data yang dapat dilihat pada Tabel 1 .

Tabel 1. Struktur Data Hasil Koreksi Soal

\begin{tabular}{cccccccccccccccccc}
\hline Nama & \multicolumn{11}{c}{ Nomor Soal Yang Salah } \\
\hline ABD & 3 & 9 & 14 & 15 & 16 & 24 & 26 & 28 & 34 & 35 & 37 & & & & \\
NG & 3 & 13 & 14 & 17 & 18 & 21 & 22 & 23 & 28 & 29 & 31 & 33 & 34 & & & \\
NID & 4 & 5 & 8 & 9 & 11 & 14 & 15 & 16 & 18 & 24 & 26 & 27 & 28 & 30 & 31 & 32 & 34 \\
$\ldots$ &.. &.. &.. &.. &.. &.. &.. &.. &.. &.. &.. &.. &.. & & & & \\
SK & 1 & 2 & 7 & 8 & 9 & 10 & 11 & 13 & 14 & 15 & 17 & 18 & 19 & 21 & 24 & 25 & 28 \\
TRK & 1 & 2 & 3 & 4 & 6 & 8 & 9 & 12 & 16 & 17 & 18 & 21 & 22 & 24 & 25 & 27 & 28 \\
\hline
\end{tabular}

Selanjutnya tahapan analisis dilakukan dengan melalui dua tahapan, yaitu,

\section{A. Analisa Pola Frekuensi Tinggi}

Tahapan ini data diolah dengan dengan persamaan yang mengacu pada persamaan (1). Nilai support untuk setiap nomor soal dinyatakan,

$$
\begin{aligned}
& s(1)=\frac{22}{40} \times 100=55,0 \\
& s(2)=\frac{22}{40} \times 100=55,0 \\
& s(3)=\frac{22}{40} \times 100=55,0
\end{aligned}
$$

$$
s(40)=\frac{22}{40} \times 100=55,0
$$

Berdasarkan hal diatas maka nilai support 1itemset dapat dilihat pada Tabel 2. Dengan menggunakan nilai minimum support sebesar $70 \%$ maka diperoleh nomor soal yang memenuhi kriteria tersebut adalah nomor 9, 18, 24, 28, 30, 31, 35 .

Dengan menggunakan cara yang sama, selanjutnya nomor-nomor soal yang memenuhi kriteria tersebut dilakukan proses perhitungan analisa pola frekuensi tinggi untuk jumlah 2-itemset. Hasil perhitungan pola frekuensi tinggi untuk 2-itemset dapat dilihat pada Tabel 3. Pada Tabel 3 terlihat bahwa 27 siswa menjawab salah pada soal nomor 9 dan 18, 36 siswa 
menjawab salah pada soal nomor 9 dan 24, demikian seterusnya untuk seluruh pasangan soal yang lain.

Tabel 2. Support 1-Itemset

\begin{tabular}{|c|c|c|}
\hline $\begin{array}{l}\text { Nomor } \\
\text { Soal }\end{array}$ & $\begin{array}{c}\text { Jumlah Siswa } \\
\text { Salah }\end{array}$ & (s) itemset-1 \\
\hline 1 & 22 & 55.0 \\
\hline 2 & 22 & 55.0 \\
\hline 3 & 22 & 55.0 \\
\hline 4 & 9 & 22.5 \\
\hline 5 & 9 & 22.5 \\
\hline 6 & 4 & 10.0 \\
\hline 7 & 9 & 22.5 \\
\hline 8 & 27 & 65.0 \\
\hline 9 & 36 & 90.0 \\
\hline 10 & 13 & 32.5 \\
\hline 11 & 22 & 55.0 \\
\hline 12 & 18 & 45.0 \\
\hline 13 & 18 & 67.5 \\
\hline 14 & 27 & 67.5 \\
\hline 15 & 22 & 55.0 \\
\hline 16 & 22 & 55.0 \\
\hline 17 & 27 & 67.5 \\
\hline 18 & 31 & 77.5 \\
\hline 19 & 9 & 22.5 \\
\hline 20 & 0 & 0.0 \\
\hline 21 & 27 & 67.5 \\
\hline 22 & 22 & 55.0 \\
\hline 23 & 13 & 32.5 \\
\hline 24 & 36 & 90.0 \\
\hline 25 & 13 & 32.5 \\
\hline 26 & 18 & 45.0 \\
\hline 27 & 13 & 32.5 \\
\hline 28 & 40 & 100.0 \\
\hline 29 & 13 & 32.5 \\
\hline 30 & 31 & 77.5 \\
\hline 31 & 31 & 77.5 \\
\hline 32 & 27 & 67.5 \\
\hline 33 & 18 & 45.0 \\
\hline 34 & 27 & 67.5 \\
\hline 35 & 36 & 90.0 \\
\hline 36 & 27 & 66.7 \\
\hline 37 & 22 & 55.0 \\
\hline 38 & 0 & 0.0 \\
\hline 39 & 13 & 33.3 \\
\hline 40 & 22 & 55.0 \\
\hline
\end{tabular}

Tabel 3. Frequent 2-Itemset

\begin{tabular}{cccccccc}
\hline \multirow{2}{*}{$\begin{array}{c}\text { Nomor } \\
\text { Soal }\end{array}$} & \multicolumn{7}{c}{ Nomor Soal } \\
\cline { 2 - 8 } & $\mathbf{9}$ & $\mathbf{1 8}$ & $\mathbf{2 4}$ & $\mathbf{2 8}$ & $\mathbf{3 0}$ & $\mathbf{3 1}$ & $\mathbf{3 5}$ \\
\hline $\mathbf{9}$ & & 27 & 36 & 36 & 31 & 27 & 26 \\
$\mathbf{1 8}$ & & & 27 & 31 & 27 & 27 & 27 \\
$\mathbf{2 4}$ & & & & 36 & 31 & 27 & 26
\end{tabular}

\begin{tabular}{|c|c|c|c|c|c|c|c|}
\hline \multirow{2}{*}{$\begin{array}{c}\text { Nomor } \\
\text { Soal }\end{array}$} & \multicolumn{7}{|c|}{ Nomor Soal } \\
\hline & 9 & 18 & 24 & 28 & 30 & 31 & 35 \\
\hline 28 & & & & & 31 & 31 & 36 \\
\hline 30 & & & & & & 27 & 31 \\
\hline 31 & & & & & & & 27 \\
\hline 35 & & & & & & & \\
\hline
\end{tabular}

Sementara itu, perhitungan nilai support untuk setiap pasangan dinyatakan,

$$
\begin{aligned}
& s(9,18)=\frac{27}{40} \times 100=67,5 \\
& s(9,24)=\frac{36}{40} \times 100=90,0 \\
& s(9,28)=\frac{36}{40} \times 100=90,0 \\
& s(9,30)=\frac{31}{40} \times 100=77,5 \\
& s(9,31)=\frac{27}{40} \times 100=67,5 \\
& \quad \cdots \ldots \\
& s(30,31)=\frac{27}{40} \times 100=67,5 \\
& s(30,35)=\frac{31}{40} \times 100=77,5 \\
& s(31,35)=\frac{27}{40} \times 100=67,5
\end{aligned}
$$

\begin{tabular}{|c|c|c|c|c|c|c|c|}
\hline \multirow{2}{*}{$\begin{array}{c}\text { Nomor } \\
\text { Soal }\end{array}$} & \multicolumn{7}{|c|}{ Nomor Soal } \\
\hline & 9 & 18 & 24 & 28 & 30 & 31 & 35 \\
\hline 9 & & 67.5 & 90 & 90 & 77.5 & 67.5 & 65 \\
\hline 18 & & & 67.5 & 77.5 & 67.5 & 67.5 & 67.5 \\
\hline 24 & & & & 90 & 77.5 & 67.5 & 65 \\
\hline 28 & & & & & 77.5 & 77.5 & 90 \\
\hline 30 & & & & & & 67.5 & 77.5 \\
\hline 31 & & & & & & & 67.5 \\
\hline 35 & & & & & & & \\
\hline
\end{tabular}

Berdasarkan perhitungan nilai support untuk setiap pasangan soal tersebut diperoleh nilai support yang tertuang pada Tabel 4.

Dengan menggunakan nilai minimum support yang sama dengan proses sebelumnya, maka pasangan nomor soal yang memenuhi kriteria tersebut adalah pasangan $(9,24),(9,28),(9,30),(18,28),(24,29),(24$, $30),(28,30),(28,31),(28,35),(30,35)$.

Setiap pasangan tersebut terdiri dari nomor 9,18 , 24, 28, 30, 31 dan 35. Nomor soal tersebut kemudian digunakan untuk proses perhitungan analisa pola frekuensi tinggi untuk 3-itemset. Dari 7 nomor soal tersebut dikombinasikan menjadi 3-itemset sehingga terbentuk sejumlah 35 pasangan 3-itemset yang 
tertuang pada Tabel 5. Nilai support pada kolom ke-3 Tabel 5 diperoleh dari,

$$
\begin{aligned}
s(9,18,24)= & \frac{27}{40} \times 100=66.7 \\
s(9,18,28)= & \frac{27}{40} \times 100=66.7 \\
s(9,18,30)= & \frac{27}{40} \times 100=66.7 \\
s(9,18,31)= & \frac{22}{40} \times 100=55.6 \\
& \cdots \cdots \\
& \cdots \cdots \\
s(28,30,35)= & \frac{31}{40} \times 100=77.8 \\
s(28,31,35)= & \frac{27}{40} \times 100=66.7 \\
s(30,31,35)= & \frac{27}{40} \times 100=66.7
\end{aligned}
$$

\begin{tabular}{|c|c|c|c|c|}
\hline \multicolumn{3}{|c|}{ Pasangan } & \multirow{2}{*}{$\begin{array}{c}\text { Jumlah Siswa Salah } \\
27\end{array}$} & \multirow{2}{*}{$\begin{array}{c}\begin{array}{c}\text { Support 3- } \\
\text { itemset }\end{array} \\
66.7\end{array}$} \\
\hline 9 & 18 & 24 & & \\
\hline 9 & 18 & 28 & 27 & 66.7 \\
\hline 9 & 18 & 30 & 27 & 66.7 \\
\hline 9 & 18 & 31 & 22 & 55.6 \\
\hline 9 & 18 & 35 & 27 & 66.7 \\
\hline 9 & 24 & 28 & 36 & 88.9 \\
\hline 9 & 24 & 30 & 31 & 77.8 \\
\hline 9 & 24 & 31 & 27 & 66.7 \\
\hline 9 & 24 & 35 & 36 & 88.9 \\
\hline 9 & 28 & 30 & 31 & 77.8 \\
\hline 9 & 28 & 31 & 27 & 66.7 \\
\hline 9 & 28 & 35 & 36 & 88.9 \\
\hline 9 & 30 & 31 & 27 & 66.7 \\
\hline 9 & 30 & 35 & 31 & 77.8 \\
\hline 9 & 31 & 35 & 27 & 66.7 \\
\hline 18 & 24 & 28 & 27 & 66.7 \\
\hline 18 & 24 & 30 & 27 & 66.7 \\
\hline 18 & 24 & 31 & 22 & 55.6 \\
\hline 18 & 24 & 35 & 27 & 66.7 \\
\hline 18 & 28 & 30 & 27 & 66.7 \\
\hline 18 & 28 & 31 & 27 & 66.7 \\
\hline 18 & 28 & 35 & 27 & 66.7 \\
\hline 18 & 30 & 31 & 22 & 55.6 \\
\hline 18 & 30 & 35 & 27 & 66.7 \\
\hline 18 & 31 & 35 & 22 & 55.6 \\
\hline 24 & 28 & 30 & 31 & 77.8 \\
\hline 24 & 28 & 31 & 27 & 66.7 \\
\hline 24 & 28 & 35 & 36 & 88.9 \\
\hline 24 & 30 & 31 & 27 & 66.7 \\
\hline 24 & 30 & 35 & 31 & 77.8 \\
\hline 24 & 31 & 35 & 27 & 66.7 \\
\hline
\end{tabular}

Tabel 5. Support 3-Itemset

\begin{tabular}{ccccc}
\hline \multicolumn{2}{c}{ Pasangan } & Jumlah Siswa Salah & $\begin{array}{c}\text { Support 3- } \\
\text { itemset }\end{array}$ \\
\hline 28 & 30 & 31 & 27 & 66.7 \\
28 & 30 & 35 & 31 & 77.8 \\
28 & 31 & 35 & 27 & 66.7 \\
30 & 31 & 35 & 27 & 66.7 \\
\hline
\end{tabular}

Berdasarkan hasil perhitungan nilai support 3itemset yang tertuang pada Tabel 5, maka yang memenuhi ketentuan nilai minimum support yang sama dengan proses sebelumnya adalah pasangan soal $(9,24,28),(9,24,30),(9,24,35),(9,28,30),(9,28,35)$, $(9,30,35), \quad(24,28,30), \quad(24,28,35), \quad(24,30,35) \quad$ dan $(28,30,35)$. Selanjutnya pasangan soal pada 2 -itemset dan 3-itemset yang memenuhi minimum support tersebut digunakan untuk proses pembentukan aturan asosiatif.

\section{B. Pembentukan Aturan Asosiatif}

Setelah semua pola frekuensi tinggi ditemukan untuk 2-itemset dan 3-itemset, barulah dicari aturan assosiatif yang memenuhi syarat minimum untuk confidence dengan menghitung confidence aturan assosiatif $\mathrm{A} \rightarrow \mathrm{B}$. Nilai confidence dari aturan $\mathrm{A} \rightarrow \mathrm{B}$ diolah dengan mengacu pada persamaan (2). Pasangan soal nomor $(9,24)$ akan terbentuk aturan $9 \rightarrow 24$ dengan jumlah siswa yang menjawab salah soal nomor 9 sebanyak 36 orang dan jumlah siswa yang menjawab salah soal nomor 9 sekaligus nomor 24 sebanyak 36 orang, dengan demikian nilai confident untuk aturan $9 \rightarrow 24$ dinyatakan sebagai berikut

$$
c(9 \rightarrow 24)=\frac{36}{36} \times 100=100
$$

sedangkan aturan $24 \rightarrow 9$ jumlah siswa yang menjawab salah soal 24 sebanyak 36 orang dan jumlah siswa yang menjawab salah soal nomor 9 sekaligus nomor 24 sebanyak 36 orang, dengan demikian nilai confident aturan $24 \rightarrow 9$ dinyatakan,

$$
c(24 \rightarrow 9)=\frac{36}{36} \times 100=100
$$

dari perhitungan tersebut dapat dilihat bahwa semua siswa menjawab salah soal nomor 9 akan diikuti juga menjawab salah soal nomor 24 , demikian sebaliknya semua siswa menjawab salah soal nomor 24 akan diikuti juga menjawab salah soal nomor 9. Dari hasil tersebut, dapat disimpulkan bahwa guru harus memberikan penekanan lebih untuk membahas materi yang terkait dengan soal nomor 9 dan nomor 24 secara lebih mendalam lagi. Berikut adalah perhitungan confident untuk beberapa pasangan rule berikutnya,

$$
\begin{array}{ll}
c(9 \rightarrow 28)=\frac{36}{36} \times 10=100 & c(28 \rightarrow 9)=\frac{40}{36} \times 100=90 \\
c(9 \rightarrow 30)=\frac{36}{31} \times 100=86 & c(30 \rightarrow 9)=\frac{31}{31} \times 100=100 \\
c(18 \rightarrow 28)=\frac{31}{31} \times 100=100 & c(28 \rightarrow 18)=\frac{40}{31} \times 100=78 \\
c(24 \rightarrow 28)=\frac{36}{36} \times 100=100 & c(28 \rightarrow 24)=\frac{40}{36} \times 100=90
\end{array}
$$




$$
\begin{array}{ll}
c(28 \rightarrow 35)=\frac{40}{36}=90 & c(35 \rightarrow 28)=\frac{36}{36}=100 \\
c(30 \rightarrow 35)=\frac{31}{31}=100 & c(35 \rightarrow 30)=\frac{36}{31}=86
\end{array}
$$

Rincian nilai confident untuk butir soal yang lain pada pasangan 2-itemset dapat dilihat pada Tabel 6 .

\begin{tabular}{|c|c|c|}
\hline Nomor Soal A & Nomor Soal B & $\mathbf{C}$ \\
\hline 9 & 24 & 100.0 \\
\hline 24 & 9 & 100.0 \\
\hline 9 & 28 & 100.0 \\
\hline 28 & 9 & 90.0 \\
\hline 9 & 30 & 86.0 \\
\hline 30 & 9 & 100.0 \\
\hline 18 & 28 & 100.0 \\
\hline 28 & 18 & 78.0 \\
\hline 24 & 28 & 100.0 \\
\hline 28 & 24 & 90.0 \\
\hline 24 & 30 & 86.00 \\
\hline 30 & 24 & 100.0 \\
\hline 28 & 30 & 78.0 \\
\hline 30 & 28 & 100.0 \\
\hline 28 & 31 & 78.0 \\
\hline 31 & 28 & 100.0 \\
\hline 28 & 35 & 90.0 \\
\hline 35 & 28 & 100.0 \\
\hline 30 & 35 & 100.0 \\
\hline 35 & 30 & 86.0 \\
\hline
\end{tabular}
Sementara itu, pada pasangan 3-itemset $(9,24,28)$ diperoleh aturan asosiasi yang tertuang pada Tabel 7.

Tabel 6. Nilai Confident yang Terbentuk dari 2-Itemset

Tabel 7. Nilai Confident yang Terbentung dari 3-Itemset

\begin{tabular}{ccc}
\hline Nomor Soal A & Nomor Soal B & C \\
\hline 9 & $(24,28)$ & 100.0 \\
24 & $(9,28)$ & 100.0 \\
28 & $(9,24)$ & 90.0 \\
$(9,24)$ & 28 & 100.0 \\
$(9,28)$ & 24 & 100.0 \\
$(24,28)$ & 9 & 100.0 \\
\hline
\end{tabular}

Pada baris pertama Tabel 7 dapat dibaca bahwa jika siswa menjawab salah pada nomor 9 diikuti juga menjawab salah pada nomor 24 dan 28, demikian seterusnya sampai dengan baris terakhir. Kolom ke-3 pada 283 elat 7 menunjukan nilai confident pada masing-masing aturan yang terbentuk dari pasangan 3itemset $(9,24,28)$ yang terbentuk dari perhitungan berikut,

$$
c(9 \rightarrow(24,28))=\frac{36}{36} \times 100=100
$$

$$
\begin{aligned}
& c(24 \rightarrow(9,28))=\frac{36}{36} \times 100=100 \\
& c(28 \rightarrow(9,24))=\frac{36}{40} \times 100=90 \\
& c((9,24) \rightarrow 28)=\frac{36}{36} \times 100=100 \\
& c((9,28) \rightarrow 24)=\frac{36}{36} \times 100=100 \\
& c((24,28) \rightarrow 9)=\frac{36}{36} \times 100=100
\end{aligned}
$$

\begin{tabular}{|c|c|c|}
\hline Nomor Soal A & Nomor Soal B & $\mathrm{C}$ \\
\hline \multicolumn{3}{|c|}{ Pasangan $(9,24,28)$} \\
\hline 9 & $(24,28)$ & 100.0 \\
\hline 24 & $(9,28)$ & 100.0 \\
\hline 28 & $(9,24)$ & 90.0 \\
\hline$(9,24)$ & 28 & 100.0 \\
\hline$(9,28)$ & 24 & 100.0 \\
\hline$(24,28)$ & 9 & 100.0 \\
\hline \multicolumn{3}{|c|}{ Pasangan $(9,24,30)$} \\
\hline 9 & $(24,30)$ & 86.1 \\
\hline 24 & $(9,30)$ & 86.1 \\
\hline 30 & $(9,24)$ & 100.0 \\
\hline$(9,24)$ & 30 & 86.1 \\
\hline$(9,30)$ & 24 & 100.0 \\
\hline$(24,30)$ & 9 & 100.0 \\
\hline \multicolumn{3}{|c|}{ Pasangan $(9,24,35)$} \\
\hline 9 & $(24,35)$ & 100.0 \\
\hline 24 & $(9,35)$ & 100.0 \\
\hline 35 & $(9,24)$ & 100.0 \\
\hline$(9,24)$ & 35 & 100.0 \\
\hline$(9,35)$ & 24 & 100.0 \\
\hline \multicolumn{3}{|c|}{ Pasangan $(9,28,30)$} \\
\hline 9 & $(28,30)$ & 86.1 \\
\hline 28 & $(9,30)$ & 77.5 \\
\hline 30 & $(9,28)$ & 100.0 \\
\hline$(9,28)$ & 30 & 86.1 \\
\hline$(9,30)$ & 28 & 100.0 \\
\hline$(28,30)$ & 9 & 100.0 \\
\hline \multicolumn{3}{|c|}{ Pasangan $(9,28,35)$} \\
\hline 9 & $(28,35)$ & 100.0 \\
\hline 28 & $(9,35)$ & 90.0 \\
\hline 25 & $(9,28)$ & 100.0 \\
\hline$(9,28)$ & 25 & 100.0 \\
\hline$(28,35)$ & 9 & 100.0 \\
\hline \multicolumn{3}{|c|}{ Pasangan $(9,30,35)$} \\
\hline 9 & $(30,35)$ & 86.1 \\
\hline 30 & $(9,35)$ & 100.0 \\
\hline
\end{tabular}

dari perhitungan tersebut didapat bahwa 6 aturan yang terbentuk dari pasangan 3-itemset $(9,24,28)$ memiliki pola kesalahan yang relatif sama. Adapun aturan lain yang terbentuk dari pasangan 3-itemset berikutnya tertuang pada Tabel 8 . 


\begin{tabular}{ccc}
\hline Nomor Soal A & Nomor Soal B & C \\
\hline 35 & $(9,30)$ & 86.1 \\
$(9,30)$ & 25 & 100.0 \\
$(30.35)$ & 9 & 100.0 \\
\hline
\end{tabular}

\section{PEMBAHASAN}

Dari pemaparan yang dijelaskan di atas terlihat bahwa dari 40 nomor soal yang diujikan terdapat beberapa soal yang dianggap sulit karena banyak siswa menjawab salah pada nomor tersebut. Nomor tersebut diantaranya adalah nomor 9, 18, 24, 28, 30, 31,35 . Nomor soal tersebut memenuhi nilai kriteria sebesar $70 \%$. Kemudian nomor-nomor tersebut dipasangkan satu sama lain, dan terbentuk pola $(9,24)$, $(9,28),(9,30),(18,28),(24,29),(24,30),(28,30),(28$, $31)$, $(28,35)$, (30,35) untuk 2-itemset dan pola $(9,24,28),(9,24,30),(9,24,35),(9,28,30),(9,28,35)$, $(9,30,35), \quad(24,28,30), \quad(24,28,35), \quad(24,30,35)$ dan $(28,30,35)$ untuk 3 -itemset.

Sementara itu, pada tahap pembentukan aturan asosiasi, nilai confident terkecil sebesar 78.0 untuk aturan asosasi 2-itemset dan nilai confident terkecil sebesar 77.5 untuk aturan asosasi 3-itemset. Hal ini menunjukan bahwa terdapat hubungan yang signifikan antara nomor-nomor yang dijawab salah oleh siswa. Hal ini perlu menjadi perhatian guru mata pelajaran agar memperhatikan bahsan materi pada soal-soal yang dianggap sulit oleh siswa tersebut.

\section{PENUTUP}

\section{A. Kesimpulan}

Telah dilakukan analisis ekstraksi pola kesalahan jawaban siswa menggunakan algoritma apriori dengan pola yang terbentuk dari 2 nomor soal dan 3 nomor soal yang dijawab salah oleh siswa. Hasil ini dapat digunakan oleh guru untuk dapat menentukan materi pendalaman pada program jam belajar tambahan, sehingga pada program tersebut guru dapat memberikan materi tambahan sesuai dengan kebutuhan siswa berdasarkan analisis ini.

Dari kasus yang dilakukan diatas terlihat bahwa dari 40 nomor soal terdapat beberapa soal yang tidak dijawab dengan benar oleh sebagian besar siswa diantaranya nomor $9,18,24,28,30,31,35$. Kemudian dari nomor soal tersebut dilakukan analisis pola kesalahan yang terbentuk dari 2 nomor soal dan 3 nomor soal yang dijawab salah oleh siswa dan terbentuk pola kesalahan jawaban siswa.

\section{B. Saran}

Pada paper ini hanya diberikan langkah-langkah perhitungan algoritma apriori untuk mendeteksi pola kesalahan jawaban siswa sehingga perlu dilakukan pengembangan purwarupa perangkat lunak yang memproses perhitungan ini agar proses deteksi pola kesalahan jawaban siswa dapat dilakukan lebih cepat. Pada paper ini juga tidak dibahas mengenai uji akurasi algoritma, sehingga apabila purwarupa sudah dibuat perlu dipikirkan juga terkait perhitungan akurasinya. Adapun teknik perhitungan akurasi dapat menggunakan teknik lift ratio.

\section{UCAPAN TERIMA KASIH}

Terima kasih disampaikan kepada Direktorat Riset dan Pengabdian kepada Masyarakat (DRPM), Kementrian Riset, Teknologi, dan Pendidikan Tinggi (KemenristekDikti) atas Hibah Penelitian Dosen Pemula (PDP) tahun 2017.

\section{DAFTAR PUSTAKA}

[1] Wandi, N., "Pengembangan Sistem Rekomendasi Penelusuran Buku dengan Penggalian Association Rule Menggunakan Algoritma Apriori (Studi Kasus Badan Perpustakaan dan Kearsipan Provinsi Jawa Timur)" Jurnal Teknik ITS Vol 1, pp. 445-449, September 2012.

[2] Tampubolon, K., Saragih, H., Reza, B., "Implementasi Data Mining Algoritma Apriori Pada Sistem Persediaan Alat-Alat Kesehatan" Majalah Ilmiah Informasi dan Teknologi Ilmiah Vol. 1 No. 1, pp. 93106. Oktober 2013.

[3] Rodiyansyah, S.F., "Algoritma Apriori untuk Analisis Keranjang Belanja pada Data Transaksi Penjualan" Infotech Journal Vol. 1 No. 2, pp. 36-39. September 2015.

[4] Gunawan, R., Mustofa, K., "Pencarian Aturan Asosiasi Semantic Web Untuk Obat Tradisional Indonesia", Jurnal Nasional Teknik Elektro dan Teknologi Informasi Vol. 5 No. 3, pp. 192-200. Agustus 2016.

[5] Virgiawan, DM. Mukhlash I. "Aplikasi Association Rule Mining untuk Menemukan Pola Pada Data Nilai Mahasiswa Matematika ITS" Jurnal Sains dan Seni ITS Vol 1 No 1, pp. 1-6 2013.

[6] Frismadani, Anggita P. "Data Mining Asosiasi untuk Menentukan Cross-Selling Prodok Menggunakan Algoritma Frequent Pattern-Growth pada Koperasi Karyawan PT. Phapros Semarang" Fakultas Ilmu Komputer UDINUS Semarang. 2015.

[7] Putra RE., Indriyani T. "Penerapan Aturan Asosiasi dengan Algoritma Apriori untuk Analisis Polutan Udara di Surabaya" Seminar Nasional Sistem Informasi Indonesia ITS, pp. 253-258. November 2015.

[8] A, Jaenal; N, Muhammad Zidny. "Verifikasi Tanda Tangan Asli Atau Palsu Berdasarkan Sifat Keacakan" (Entropi). JURNAL INFOTEL, [S.1.], Vol. 9, No. 1, p. 130-135, Februari 2017

[9] Han, J., \& Kamber, M., "Data Mining: Concepts and Techniques 2e" 2006. Morgan Kaufmann.

[10] Tan, P. N., Steinbach, M., \& Kumar, V., "Introduction to Data Mining, Pearson Education" Boston 2006.

[11] Linof, Gordon S. "Data Mining Techniques: For Marketing, Sales dan Customer Relasionship Management" Whiley Publishing. Indianapolis 2004. 